\title{
Hubungan Motivasi Kerja dan Sistem Pengembangan Pegawai terhadap Kinerja Pegawai di Koperasi Dharmayukti Pengadilan Tata Usaha Negara Palembang
}

\author{
Wendy Liana \\ Program Studi Administrasi Perkantoran, Akademi Sekretari dan Manajemen Sriwijaya \\ Jalan Letnan Murod No 35 KM 5 Palembang \\ Email: wendy_liana80@yahoo.com
}

\begin{abstract}
Employees are the most important assets in an agency, so that quality improvement needs to be an important concern in an effort to achieve agency goals effectively and efficiently. In every management activity, efforts should be made to align the goals of employees so that in the end the objectives of the agency can be achieved as much as possible. Performance appraisal is the most reliable tool for managers to control human resources and productivity. Performance appraisal can be used effectively in directing employee behavior, in order to produce high quality and volume of human resources. Managers can use the operational performance process to set the direction of work in selecting, training, guiding career planning, and rewarding competent employees. The essence of employment is basically regulation, potential mobilization, motivation process, and human resource development in fulfilling satisfaction through his work. This is useful for achieving the goals of the individual, organization, or community in which he works. Decisions made regarding manpower are strongly influenced by the philosophy adopted by the leader regarding labor empowerment. For example, views on work motivation, and the concept of labor. From this point of view, an employment pattern will be formed that is adjusted to the image of the leader. Every government and private agency will always try to improve the effectiveness of employees' work. This can be done by developing employee work. Most leaders are very supportive of employee development. The lower the job level, the more labor supply there is. The positions leading to special skills are not filled because of the lack of employees who meet the requirements. A person is trained to carry out the basic arrangements essential for the job, the most common types of training being fieldwork, meetings or discussions.
\end{abstract}

Keywords: Work Motivation, Employee Development, Employee Performance

\begin{abstract}
ABSTRAK
Pegawai merupakan aset yang paling penting dalam suatu Instansi, sehingga peningkatan kualitasnya perlu menjadi perhatian penting dalam upaya pencapaian tujuan instansi secara efektif dan efisien. Dalam setiap kegiatan manajemen, keselarasan tujuan para pegawai perlu diupayakan agar pada akhirnya nanti tujuan instansi dapat dicapai semaksimal mungkin. Penilaian kinerja merupakan alat yang paling dapat dipercaya oleh manajer dalam mengontrol sumber daya manusia dan produkivitas. Penilaian kinerja dapat digunakan secara efektif dalam mengarahkan prilaku pegawai, dalam rangka menghasilkan sumber daya manusia dengan kualitas dan volume yang tinggi. Manajer dapat menggunakan proses operasional kinerja untuk mengatur arah kerja dalam memilih, melatih, membimbing perencanaan karir, serta memberi penghargaan kepada pegawai yang berkompeten. Hakekat ketenagakerjaan pada intinya adalah pengaturan, mobilisasi potensial, proses motivasi, dan pengembangan sumber daya manusia dalam memenuhi kepuasan melalui karyanya. Hal ini berguna untuk tercapainya tujuan individu, organisasi, ataupun komunitas di mana ia bekarya. Keputusan yang diambil tentang ketenaga kerjaan sangat dipengaruhi oleh falsafah yang dianut oleh pemimpin tentang pendayagunaan tenaga kerja. Misalnya, pandangan tentang motivasi kerja, dan konsep tentang tenaga kerja. Dari pandangan tersebut akan terbentuk pola ketenaga kerjaan yang disesuaikan dengan gambaraan pemimpin. Setiap instansi pemerintah maupun swasta akan selalu berusaha meningkatkan efektifitas kerja pegawai. Hal ini dapat dilakukan dengan cara pengembangan kerja pegawainya. Kebanyakan pemimpin sangat mendukung pengembangan pegawainya. Makin rendah tingkat pekerjaan, makin banyak persediaan tenaga kerja yang ada. Kedudukan yang menuntun kecakapan khusus tidak terisi karena kurangnya pegawai yang memenuhi persyaratan. Seseorang dilatih untuk melakukan penyelenggaraan dasar yang penting bagi pekerjaan itu, jenis yang paling umum dari pelatihan itu adalah latihajabatan, pertemuan atau diskusi.
\end{abstract}

Kata kunci : Motivasi Kerja, Pengembangan Pegawai, Kinerja Pegawai 


\section{Pendahuluan}

Perkembangan pembangunan Indonesia yang meningkat tidak lepas dari keterlibatan instansi baik pemerintah ataupun swasta yang memiliki kemampuan dalam melihat perkembangan dunia. Salah satu yang paling berperan didalam menciptakan suatu instansi pemerintah yang memiliki kemampuan dalam perkembangannya adalah tenaga kerja atau sumber daya manusia. Permasalahan dalam pembangunan Indonesia memang tidak terlepas dari pembangunan sumber daya manusia yang menginginkan adanya peningkatan kualitas manusia Indonesia.

Dalam rangka meningkatkan citra, kerja dan kinerja instansi dan pemerintah menuju ke arah profesionalisme dan menunjang terciptanya pemerintah yang baik, perlu adanya penyatuan arah dan pandangan bagi segenap jajaran pegawai pemerintah yang dapat dipergunakan sebagai pedoman atau acuan dalam melaksanakan tugasnya diseluruh bidang tugas dan unit organisasi Instansi pemerintah secara terpadu. Kinerja pegawai merupakan hasil kerja yang dapat dicapai seseorang atau sekelompok orang dalam suatu organisasi sesuai wewenang dan tanggung jawab masing-masing dalam rangka mewujudkan tujuan organisasi.

Karyawan atau pegawai merupakan aset yang paling penting dalam suatu Instansi, sehingga peningkatan kualitasnya perlu menjadi perhatian penting dalam upaya pencapaian tujuan instansi secara efektif dan efisien. Dalam setiap kegiatan manajemen, keselarasan tujuan para pegawai perlu diupayakan agar pada akhirnya nanti tujuan instansi dapat dicapai semaksimal mungkin.

Penilaian kinerja merupakan alat yang paling dapat dipercaya oleh manajer dalam mengontrol sumber daya manusia dan produkivitas (Handayani, 2018; Neksen, dkk., 2021; Khoyrun dkk., 2020). Proses penilaian kinerja dapat digunakan secara efektif dalam mengarahkan prilaku pegawai, dalam rangka menghasilkan sumber daya manusia dengan kualitas dan volume yang tinggi. Manajer dapat menggunakan proses operasional kinerja untuk mengatur arah kerja dalam memilih, melatih, membimbing perencanaan karier, serta memberi penghargaan kepada pegawai yang berkompeten. (Nursalam, 2009).

Hakekat ketenagakerjaan pada intinya adalah pengaturan, mobilisasi potensial, proses motivasi, dan pengembangan sumber daya manusia dalam memenuhi kepuasan melalui karyanya (Erwinsyah, 2016; Adipati, 2018; Anwar, 2018). Hal ini berguna untuk tercapainya tujuan individu, organisasi, ataupun komunitas di mana ia bekarya. Keputusan yang diambil tentang ketenaga kerjaan sangat dipengaruhi oleh falsafah yang dianut oleh pemimpin tentang pendayagunaan tenaga kerja. Misalnya, pandangan tentang motivasi kerja, dan konsep tentang tenaga kerja. Dari pandangan tersebut akan terbentuk pola ketenaga kerjaan yang disesuaikan dengan gambaraan pemimpin (Suarli, 2002).

Setiap instansi pemerintah maupun swasta akan selalu berusaha meningkatkan efektifitas kerja pegawai. Hal ini dapat dilakukan dengan cara pengembangan kerja pegawainya. Kebanyakan pemimpin sangat mendukung pengembangan pegawainya. Makin rendah tingkat pekerjaan, makin banyak persediaan tenaga kerja yang ada. Kedudukan yang menuntun kecakapan khusus tidak terisi karena kurangnya pegawai yang memenuhi persyaratan. Seseorang dilatih untuk melakukan penyelenggaraan dasar yang penting bagi pekerjaan itu, jenis yang paling umum dari pelatihan itu adalah latihajabatan, pertemuan atau diskusi.

Motivasi adalah mempersoalkan bagaimana cara mendorong gairah kerja bawahan, agar mereka bekerja keras dengan memberikan semua kemampuan dan keterampilan untuk mewujudkan tujuan perusahaan (Malayu, 2015:23). Motivasi kerja dibagi menjadi beberapa jenis. Jenis-jenis motivasi menurut Winardi (2016:5) dapat bersifat negatif dan positif.

Motivasi berasal dari bahasa latin "Movere" yang artinya menimbulkan pergerakan. Motivasi merupakan kekuatan psikologis untuk menggerakkan seseorang kearah beberapa jenis tindakan (Haggard, 1989) dan sebagai suatu kesediaan untuk menerima pembelajaran, dengan kesiapan sebagai bukti dari motivasi (Redman, 1993). Menurut Kort (1987), motivasi adalah hasil faktor internal dan eksternal sehingga motivasi menyiratkan gerakan untuk memenuhi suatu kebutuhan untuk mencapai suatu tujuan. Menurut Susilo (2007:182) motivasi kerja mampu menimbulkan dorongan atau semangat kerja atau dengan kata lain pendorong semangat kerja. Berbeda dengan pendapat Robbins (2007:113) bahwa motivasi merupakan proses yang ikut menentukan intensitas, arah, dan ketekunan individu dalam usaha mencapai sasaran.

Penelitian Martin (2012) menemukan pengaruh secara simultan antara pengembangan karir dan motivasi kerja karyawan serta secara parsial pengembangan karir berpengaruh terhadap motivasi kerja pegawai. Terdapat hubungan cukup kuat antara kedua variabel tersebut yaitu hubungan program pengembangan karir dengan motivasi kerja kpegawai. Oleh karena itu, program pengembangan karir mempunyai peranan yang cukup besar dalam meningkatkan motivasi kerja pegawai.

Pendidikan dan latihan pada dasarnya sangat dibutuhkan oleh semua bentuk organiasi besar atau kecil, termasuk pula pengadilan Tata Usaha Negara Palembang. Perkembangan usaha dan cara yang telah dilakukan dalam mencapai tujuan organisasi sebagai instansi pelayanan publik ini ditunjang oleh sistem perkembangan pegawai yang bertujuan untuk mendidik dan melatih para pegawai agar dapat menghasilkan suatu prestasi kerja yang dapat mempengaruhi dan meningkatkan kemajuan suatu instansi.

Pelaksanaan pengembangan dan pelatihan pegawai pada pengadilan Tata Usaha Negara Palembang mengalami kesulitan-kesulitan khususnya kebutuhan dana, dimana untuk melaksanakan pendidikan dan pelatihan pegawai akan membutuhkan suatu dana yang tidak sedikit sehingga badan usaha tidak mampu untuk mengadakan pengembangan pegawai yang dapat dilaksanakan secara berkelanjutan, selain itu juga Pengadilan Tata Usaha Negara Palembang menghadapi 
kesulitan lain yang berasal dari pegawai itu sendiri, kurangnya kesadaran para pegawai bahwa pengembangan pegawai sangatlah penting bagi suatu instansi dan pegawai pada khususnya, serta masyarakat pada umumnya. Implikasi dari kurangnya pelaksanaan pengembangan pegawai adalah prestasi kerja pegawai pun juga menurun seperti tingkat absensi tinggi dan banyak target yang direncanakan tidak tercapai.

Berdasarkan uraian di atas maka penulis tertarik untuk melakukan penelitian di Koperasi Dharmayukti Pengadilan Tata Usaha Negara Palembang, khususnya yang berkaitan dengan motivasi Kerja dan sistem pengembangan pegawai terhadap kinerja pegawai

\section{A. Perumusan Masalah}

Perumusan masalah yang diajukan dalam penelitian ini didasarkan pada uraian- uraian di atas adalah sebagai berikut:

1. Bagaimana hubungan motivasi kerja dan sistem pengembangan pegawai terhadap kinerja pegawai di Koperasi Dharmayukti Pengadilan Tata Usaha Negara Palembang?

2. Bagaimana peran Koperasi Dharmayukti Pengadilan Tata Usaha Negara Palembang dalam mengembangkan kinerja pegawai?

\section{B. Tujuan Penelitian}

Tujuan yang akan dicapai pada penelitian ini adalah:

1. Mengetahui hubungan motivasi kerja dan sistem pengembangan pegawai terhadap kinerja pegawai di Koperasi Dharmayukti Pengadilan Tata Usaha Negara Palembang?

2. Mengetahui bagaimana cara penerapan dalam pengembangan kinerja pegawai sehingga tercapai tujuan perusahaan?

\section{Manfaat Penelitian}

Manfaat penelitian ini adalah sebagai berikut:

1. Secara Teoritis

Penelitian ini diharapkan dapat menyumbangkan pengembangan keilmuan untuk peneliti selanjutnya, terutama yang berhubungan dengan peningkatan kinerja perusahaan tersebut.

2. Secara Praktis

Menambah khasanah keilmuan khususnya manajemen sumber daya manusia, yang berkaitan dengan pengembangan kinerja pegawai khususnya di Koperasi Dharmayukti Pengadilan Tata Usaha Negara Palembang.

\section{Tinjauan Pustaka}

A. Kerangka Pemikiran

Hipotesis yang dikemukakan dapat dijelaskan dengan gambar tentang kerangka konsep di bawah ini:

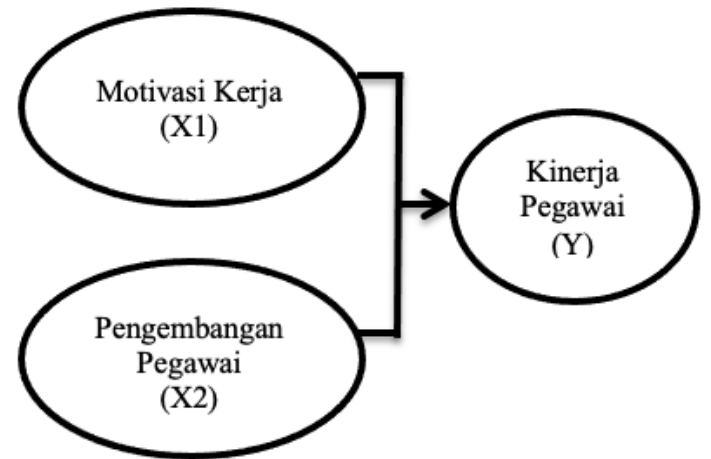

Gambar 1. Kerangka Pemikiran

B. Hipotesis

1. Pengaruh Motivasi Kerja terhadap Kinerja Pegawai Dalam penelitian yang dilakukan oleh Lucky Wulan Analisa (2011) menemukan bahwa motivasi kerja mempengaruhi kinerja pegawai secara signifikan dengan koefisien korelasi sebesar 0,439. Menurut Lucky Wulan Analisa (2011) pegawai yang memiliki motivasi kerja yang tinggi akan memberikan dampak positif bagi organisasi, sehingga tujuan organisasi akan tercapai. Selanjutnya penelitian yang dilakukan oleh Maryam Azar dan Ali Akbar Shafighi (2013) menunjukkan bahwa motivasi kerja berpengaruh positif terhadap kinerja pegawai dengan nilai koefisien regresi sebesar 0.84 .

Berdasarkan penelitian-penelitian terdahulu maka dalam penelitian ini diajukan hipotesis pertama sebagai berikut:

H1: Motivasi kerja berpengaruh positif terhadap kinerja karyawan

2. Pengaruh Pengembangan Karir terhadap Kinerja Karyawan

Dalam penelitian yang dilakukan oleh Caroline, Susan dan Oduma (2014) menunjukkan bahwa pengembangan karir berpengaruh signifikan terhadap kinerja karyawan dengan nilai signifikansi $0,03<$ 0,05 . Selanjutnya penelitian yang dilakukan oleh $\mathrm{M}$. Harlie (2012) juga menunjukkan pengembangan karir sebagai variabel bebas berpengaruh nyata secara parsial terhadap kinerja pegawai dengan nilai ( $t$ hitung sebesar 5,045 dan nilai t tabel sebesar 1,659).

Berdasarkan penelitian-penelitian terdahulu maka dalam penelitian ini diajukan hipotesis kedua sebagai berikut:

H2 : Pengembangan pegawai berpengaruh positif terhadap kinerja karyawan

\section{Metode Penelitian}

1. Populasi

Populasi adalah wilayah generalisasi yang terdiri atas: obyek/ subyek yang mempunyai kualitas dan karakteristik tertentu yang ditetapkan oleh peneliti untuk dipelajari dan kemudian ditarik kesimpulannya (Sugiyono, 2014).

Populasi penelitian ini adalah seluruh pegawai produksi Koperasi Dharmayukti Pengadilan Tata Usaha Negara Palembang sebanyak 65 orang. Metode 
pengambilan sampel dalam penelitian ini menggunakan teknik sampling jenuh, yaitu teknik penentuan sampel, apabila semua anggota populasi digunakan dalam sampel. Hal ini sering dilakukan apabila jumlah populasi relatif kecil. Sampel yang digunakan dalam penelitian ini adalah seluruh pegawai Koperasi Dharmayukti Pengadilan Tata Usaha Negara Palembang sebanyak 65 pegawai.

Metode pengumpulan data menggunakan kuesioner untuk memperoleh data primer. Sedangkan untuk data sekunder dalam penelitian ini berupa struktur organisasi perusahaan, data jumlah pegawai, serta form data penilaian kinerja pegawai

\section{Sampel}

Sampel adalah bagian dari jumlah dan karakteristik yang dimiliki oleh populasi tersebut. Jika populasi besar dan peneliti tidak mungkin mempelajari semua yang ada pada populasi, misalnya karena keterbatasan dana, tenaga dan waktu, maka peneliti dapat menggunakan sampel yang diambil dari populasi itu (Sugiyono, 2014).

Penentuan sampel dalam penelitian ini dilakukan dengan teknik Non Probability Sampling. Menurut Sugiyono (2014) Non Probability Sampling adalah teknik yang tidak memberi peluang/kesempatan yang sama bagi setiap unsur atau anggota populasi untuk dipilih menjadi sampel. Teknik Non Probability Sampling yang dipilih yaitu dengan sampling jenuh (sensus) yaitu model penarikan sampel bila semua anggota populasi dijadikan sebagai sampel. Dalam penelitian ini sampel yang akan diambil adalah seluruh pegawai Koperasi Dharmayukti Pengadilan Tata Usaha Negara Palembang yaitu sebanyak 65 orang, yang terdiri dari pegawai dengan jabatan yang berbeda-beda.

\section{Pengukuran Instrumen Penelitian}

Teknik pengukuran skor atau nilai yang digunakan dalam penelitian ini adalah memakai skala Likert. Alternatif penilaian dalam pengukuran item-item tersebut terdiri dari 5 (lima) alternatif pilihan yang mempunyai tingkatan sangat rendah sampai dengan sangat tinggi (bernilai 1 s.d. 5) yang diterapkan secara bervariasi sesuai pertanyaan.

Dalam Ghozali (2011), skala yang sering dipakai dalam penyusunan kuesioner adalah skala Likert, yaitu skala yang berisi 5 (lima) tingkat preferensi jawaban. Penentuan skor dari setiap pertanyaan dengan alternatif jawaban yang berbeda, yaitu:

Tabel 1. Skala Pengukuran Likert

\begin{tabular}{|c|c|c|}
\hline Kode & Kriteria Jawaban & Nilai \\
\hline SS & Sangat Setuju & 5 \\
\hline S & Setuju & 4 \\
\hline R & Ragu-ragu & 3 \\
\hline TS & Tidak Setuju & 2 \\
\hline STS & Sangat Tidak Setuju & 1 \\
\hline
\end{tabular}

\section{F. Jenis Data dan Sumber Daya}

1. Sumber Primer

Untuk mendukung penelitian ini dan memperoleh data yang dibutuhkan, maka jenis data yang digunakan adalah data primer yang diambil langsung dari sumber primer. Sumber primer adalah sumber data yang langsung memberikan data kepada pengumpul data. (Sugiyono, 2014).

Data primer ini dikumpulkan melalui metode wawancara dan survey dengan menggunakan kuesioner yang dibuat oleh peneliti. Kuesioner ini diperoleh dari indikator variabel, selanjutnya indikator tersebut dijadikan sebagai acuan untuk menyusun butir-butir instrumen yang berupa pernyataan.

a. Kuesioner merupakan Teknik pengumpulan data yang dilakukan dengan cara memberi seperangkat pertanyaan atau pernyataan tertulis kepada responden untuk dijawabnya (Sugiyono, 2014).

b. Wawancara

Wawancara digunakan sebagai Teknik pengumpulan data apabila peneliti ingin melakukan studi pendahuluan untuk menemukan permasalahan yang harus diteliti, dan juga apabila peneliti ingin mengetahui hal-hal dari responden yang lebih mendalam dan jumlah respondennya sedikit atau kecil (Sugiyono, 2014). Jenis wawancara yang digunakan dalam penelitian ini adalah wawancara tak berstruktur. Menurut Esterberg dalam (Sugiyono, 2014) menjelaskan wawancara tak berstruktur adalah wawancara yang bebas dimana peneliti tidak menggunakan pedoman wawancara yang telah tersusun secara sistematis dan lengkap untuk pengumpulan datanya. Pedoman wawancara yang digunakan hanya berupa garis-garis besar permasalahan yang akan ditanyakan. Wawancara tak berstruktur atau terbuka, sering digunakan dalam penelitian pendahuluan atau untuk penelitian yang lebih mendalam tentang subyek yang diteliti.

\section{Sumber Sekunder}

Menurut sumbernya, data sekunder adalah data yang diambil dari sumber sekunder. Sumber sekunder merupakan sumber yang tidak langsung memberikan data kepada pengumpul data, misalnya lewat orang lain atau lewat dokumen (Sugiyono, 2014). Adapun data sekunder yang digunakan yaitu:

a. Studi Pustaka

Studi pustaka adalah teknik pengumpulan data dengan mengadakan studi penelaahan terhadap bukubuku, jurnal, literatur-literatur, catatan-catatan, data dari internet dan lain sebagainya.

b. Dokumentasi

Dokumentasi adalah pengumpulan data yang dilakukan dengan cara mengutip langsung data yang diperoleh dari objek penelitian. Peneliti memperoleh data sekunder melalui Koperasi Dharmayukti Pengadilan Tata Usaha Negara Palembang.

\section{Hasil dan Pembahasan}

1. Pengaruh Motivasi Kerja terhadap Kinerja pegawai 
Uji regresi yang dilakukan pada variabel motivasi kerja menunjukkan hasil bahwa motivasi kerja berpengaruh positif terhadap kinerja pegawai dengan nilai standardized coefficients beta sebesar 0,200. Hal ini membuktikan bahwa semakin tinggi tingkat motivasi kerja seorang karyawan maka kinerjanya akan semakin meningkat. Jadi, dapat disimpulkan bahwa hipotesis pertama yang menyatakan bahwa motivasi kerja berpengaruh positif terhadap kinerja pegawai diterima.

Hal tersebut diperkuat dengan hasil dari analisis deskripsi variabel motivasi kerja yang menunjukkan bahwa sebagian besar pegawai Koperasi Dharmayukti Pengadilan Tata Usaha Negara Palembang memiliki penilaian yang baik terhadap tingkat motivasi kerja mereka selama bekerja di perusahaan dengan nilai ratarata angka indeks sebesar 40,95.

Hasil penelitian ini sesuai dengan hasil penelitian yang dilakukan oleh Lucky Wulan Analisa (2011), yang menunjukkan bahwa motivasi kerja berpengaruh positif kinerja karyawan dengan nilai $\beta$ sebesar 0,439 .

\section{Pengaruh Pengembangan Pegawai terhadap Kinerja} Pegawai

Uji regresi yang dilakukan pada variabel pengembangan karir menunjukkan hasil bahwa pengembangan karir berpengaruh positif terhadap kinerja pegawai dengan nilai standardized coefficients beta sebesar 0,366. Hal ini membuktikan bahwa semakin tinggi tingkat kesempatan pada pengembangan karir seorang pegawai maka kinerjanya akan semakin meningkat.

Jadi, dapat disimpulkan bahwa hipotesis kedua yang menyatakan bahwa pengembangan pegawai berpengaruh positif terhadap kinerja karyawan diterima. Hal tersebut diperkuat dengan hasil dari analisis deskripsi variabel pengembangan karir yang menunjukkan bahwa sebagian besar pegawai Koperasi Dharmayukti Pengadilan Tata Usaha Negara Palembang memiliki penilaian yang baik terhadap kesempatan pengembangan pegawai yang diberikan oleh perusahaan selama mereka bekerja dengan nilai rata-rata angka indeks sebesar 45,16.

Hasil penelitian ini sesuai dengan hasil penelitian yang dilakukan oleh Caroline, Susan dan Oduma (2014) menunjukkan bahwa pengembangan pegawai berpengaruh signifikan terhadap kinerja pegawai dengan nilai signifikansi $0,03<0,05$.

\section{Kesimpulan}

Berdasarkan hasil analisis data dan pembahasan yang telah dilakukan mengenai pengaruh motivasi kerja, pengembangan pegawai terhadap kinerja pegawai serta sesuai dengan tujuan penelitian, maka dapat disimpulkan hal-hal sebagai berikut:

1. Hipotesis pertama $\left(\mathrm{H}_{1}\right)$ yang menyatakan bahwa motivasi kerja berpengaruh positif terhadap kinerja pegawai dapat diterima. Hal tersebut terbukti dari hasil perhitungan uji t, hasil uji t menyatakan nilai $t_{\text {hitung }}$ untuk variabel motivasi kerja adalah sebesar 3,141 dengan probabilitas sebesar 0,005. Dengan menggunakan taraf signifikan $5 \%$ diperoleh nilai probabilitas lebih kecil dari 0,03. Hal ini menunjukkan bahwa $\mathrm{H}_{1}$ diterima dan $\mathrm{H}_{0}$ ditolak, sehingga dapat disimpulkan bahwa variabel motivasi kerja berpengaruh positif dan signifikan terhadap kinerja pegawai

2. Hipotesis kedua $\left(\mathrm{H}_{2}\right)$ yang menyatakan bahwa pengembangan pegawai berpengaruh positif terhadap kinerja pegawai dapat diterima. Hal tersebut terbukti dari hasil perhitungan uji t, hasil uji t menyatakan nilai $t_{\text {hitung }}$ untuk variabel pengembangan pegawai adalah sebesar 5,534 dengan probabilitas sebesar 0,000. Dengan menggunakan taraf signifikan 5\% diperoleh nilai probabilitas lebih kecil dari 0,05 . Hal ini menunjukkan bahwa $\mathrm{H}_{2}$ diterima dan $\mathrm{H}_{0}$ ditolak, sehingga dapat disimpulkan bahwa variabel pengembangan pegawai berpengaruh positif dan signifikan terhadap kinerja pegawai.

3. Berdasarkan hasil uji regresi berganda dapat disimpulkan bahwa variabel motivasi kerja berpengaruh positif terhadap kinerja pegawai sebesar 0,200 , variabel pengembangan pegawai berpengaruh positif terhadap kinerja pegawai sebesar 0,366 dan variabel komitmen organisasional mempunyai pengaruh positif sebesar 0,671 .

4. Uji koefisien determinasi $\left(\mathrm{R}^{2}\right)$ menunjukkan nilai Adjusted $R$ Square sebesar 0,741 yang berarti bahwa variabel independen motivasi kerja, pengembangan pegawai berkontribusi dalam mempengaruhi variabel dependen kinerja pegawai sebesar $74,1 \%$, sedangkan sisanya sebesar $25,9 \%$ dipengaruhi oleh variabel lainnya yang tidak dimasukkan dalam model regresi.

\section{Saran}

1. Hasil penelitian menunjukkan bahwa variabel pengembangan pegawai memiliki pengaruh cukup tinggi bagi peningkatan kinerja pegawai, karena dengan rencana pengembangan pegawai yang disusun dengan baik akan membantu pegawai dalam menentukan kebutuhan karir internal mereka di perusahaan serta dapat membantu perusahaan dalam menyesuaikan kebutuhan karir pegawai dengan tujuan organisasi yang ingin dicapai. Berdasarkan hasil analisis angka indeks tanggapan responden terhadap pernyataan pegawai selalu mengikuti pelatihan dan pendidikan yang ditetapkan oleh perusahaan memiliki nilai yang paling rendah. Oleh karena itu, agar kinerja pegawai Koperasi Dharmayukti Pengadilan Tata Usaha Negara Palembang lebih meningkat maka program pelatihan dan pendidikan yang diterapkan oleh perusahaan seharusnya secara kontinyu diikuti oleh seluruh pegawai, hal ini dilakukan bertujuan untuk meningkatkan keterampilan dan pengetahuan seluruh pegawai dalam menunjang kinerjanya.

2. Hasil penelitian menunjukkan bahwa variabel motivasi kerja memiliki pengaruh yang rendah bagi peningkatan kinerja pegawai, karena ritme kerja dan beban kerja yang relatif berbeda dengan perusahaan lain. Berdasarkan hasil analisis angka indeks tanggapan responden terhadap peryataan pegawai 
dapat menyelesaikan pekerjaan/ tugas apabila bekerja sama dengan rekan sejawat meminliki nilai yang paling rendah. Oleh karena itu, agar kinerja pegawai Koperasi Dharmayukti Pengadilan Tata Usaha Negara Palembang lebih meningkat maka kesediaan pegawai untuk bekerja sama dengan rekan sejawat lebih ditingkatkan agar beban kerja dapat terbagi sehingga pekerjaan menjadi lebih efektif dan efisien.

3. Untuk penelitian selanjutnya disarankan untuk meneliti variabel lain yang berkaitan dengan kinerja pegawai, seperti kompensasi, budaya organisasi, lingkungan kerja, dengan menggunakan objek penelitian yang berbeda.

\section{Daftar Pustaka}

Adipati, K. (2018). PENGARUH KOMPENSASI TERHADAP MOTIVASI KINERJA KARYAWAN PADA PT. MNCLEASING PALEMBANG. Jurnal Ilmiah Ekonomi Global Masa Kini, 8(2), 74-78.

Analisa, Lucky Wulan. 2011. “Analisis Pengaruh Motivasi Kerja dan Lingkungan Kerja terhadap Kinerja Karyawan (Studi pada Dinas Perindustrian dan Perdagangan Kota Semarang)".

Anwar, Y. (2018). Pengaruh kompensasi dan motivasi terhadap prestasi kerja karyawan PT. Cipta prima kontrindo Palembang-sumatera selatan. Jurnal Ilmiah Ekonomi Global Masa Kini, 8(3), 31-36.

Erwinsyah, E. (2016). Pengaruh Kompensasi Terhadap Motivasi Kerja Karyawan Pdam Tirta Musi Palembang. Jurnal Ilmiah Ekonomi Global Masa Kini, 6(1), 13-17.

Flygplan Kort. 1987. Olson, Sven-Olaf?: Amazon.com: Books

Ghozali, Imam. 2013. Aplikasi Analisis Multivariate dengan Program IBM SPSS 21 Update PLS Regresi Edisi 7. Semarang: Badan Penerbit Universitas Diponegoro.

Handayani, S. (2018). Pengaruh Kompensasi Finansial Terhadap Kinerja Pegawai Harian Lepas di Dinas Lingkungan Hidup dan Kebersihan Kota Palembang. Jurnal Ilmiah Ekonomi Global Masa Kini, 8(1), 12-20.

Harlie, M.. 2012. "Pengaruh Disiplin Kerja, Motivasi dan Pengembangan Karir terhadap Kinerja Pegawai Negeri Sipil pada Pemerintah Kabupaten Tabalong di Tanjung, Kalimantan Selatan". Jurnal Aplikasi Manajemen, Volume 10, Nomor 4.

Hasibuan, Malayu S.P. 2015. “Manajemen Sumber Daya Manusia”. Jakarta: PT Bumi Aksara.

http://heruzi.wordpress.com/2012/07/26/ kumpulan kasus-kasus nyata bentuk prilaku-stress-kerja motivasi- dan- kepuasan -kerja/

Khoyrun, H., Sutanto, A., \& Hidayat, A. C. (2020). Pengaruh Kompetensi, Motivasi, dan Lingkungan Kerja terhadap Kinerja Dosen Perguruan Tinggi
Swasta Daerah Istimewa Yogyakarta. Jurnal Ilmiah Ekonomi Global Masa Kini, 11(1), 35-39.

Maryam Azar dan Ali Akbar Shafighi. 2013. "The Effect of Work Motivation on Employee's Job Performance (Case Study: Employees of Isfahan Islamic Revolution Housing Foundation)". International Journal of Academic Research in Business and Social Sciences, Vol. 3 No. 9.

Neksen, A., Wadud, M., \& Handayani, S. (2021). Pengaruh Beban Kerja dan Jam Kerja terhadap Kinerja Karyawan pada PT Grup Global Sumatera. Jurnal Nasional Manajemen Pemasaran \& SDM, 2(2), 105-112.

Nursalam, 2009. Konsep dan penerapan Metodologi Penelitian Ilmu Keperawatan: Pedoman Skripsi, Tesis dan Instrumen Penelitian keperawatan, Edisi 2. Jakarta: Salemba Medika.

Oduma, dkk. 2014. "Influence of Career Development on Employee Performance in The Public University; A Case of Kenyatta University". International Journal of Socal Sciences. Management and Enterpreneurship 1 (2): 1-16.

Robbins, S dan Coulter, M. 2007. "Manajemen Edisi $K e-8$ ". Jakarta: PT Indeks.

R, Martin. 2012. Journal of Economic Geography. Vol. 12, Issue 1, 1-32.

Suarli, S \& Bahtiar, Y. 2002. Manajemen Keperawatan dengan Pendekatan Praktis. Jakarta: Penerbit Erlangga.

Sugiyono. 2014. Metode Penelitian Pendidikan Pendekatan Kuantitatif, Kualitatif, dan R\&D. CV Alfabeta. Bandung.

Susilo. 2007. Panduan Penelitian Tindakan Kelas. Yogyakarta: Pustaka Book Publisher.

Winardi, 2016. Manajemen Sumber Daya Manusia. Bandung: PT Remaja Rosdakarya. 